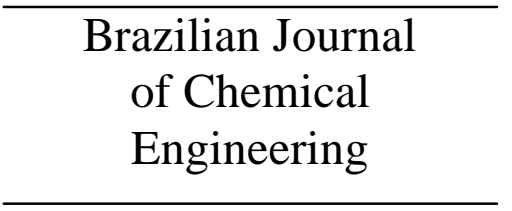

ISSN 0104-6632 Printed in Brazil

Vol. 21, No. 04, pp. 593 - 599, October - December 2004

\title{
FIRED PRODUCTS OF Cr-SMECTITE CLAYS IN NITROGEN
}

\author{
C. Volzone ${ }^{*}$ and A. M. Cesio \\ CETMIC (Centro de Tecnología de Recursos Minerales y Cerámica),CONICET-CIC-UNLP, \\ C.C. 49. Cno Centenario y 506. (1897) M. B. Gonnet. Prov. Buenos Aires, Argentina. \\ Phone: (54) (221) 484-0247/484-0167, Fax (54) (221) 471-0075, \\ E-mail: volzcris@netverk.com.ar
}

(Received: May 19, 2003 ; Accepted: May 3, 2004)

\begin{abstract}
The products of $\mathrm{Cr}$-smectite clays heated to $1350{ }^{\circ} \mathrm{C}$ in nitrogen were evaluated by $\mathrm{X}$-ray diffraction and chemical analysis. Cr-smectite clays were prepared at room temperature by contact between smectite clays and $\mathrm{Cr}$ species contained in $\mathrm{OH}-\mathrm{Cr}$ solutions. The $\mathrm{Cr}$ species were prepared using chromium nitrate solution by addition of $\mathrm{NaOH}$ solution with $\mathrm{OH} / \mathrm{Cr}=2$. Products of firing in nitrogen at the high temperature were different (magnesia chromite, donathite, iron chromium oxide and picrochromite) depending on the type of isomorphous substitution of the smectite structure and the amount of retained chromium

Keywords: Cr-smectite clays in nitrogen, fired products, X-ray diffraction and chemical analysis.
\end{abstract}

\section{INTRODUCTION}

Chromium-smectite clay materials obtained by intercalation of $\mathrm{OH}-\mathrm{Cr}$ species or $\mathrm{Cr}$ cations are used as catalysts and as adsorbents (Carr, 1985; Rengasamy and Oades, 1978; Volzone et al., 1998). The mechanisms by which the chromium clays were obtained, using $\mathrm{Cr}$ (III) ions or $\mathrm{OH}-\mathrm{Cr}(\mathrm{III})$ species from prepared solutions or from wastewater solutions, are explained in several papers (Rengasamy and Oades, 1978; Brindley and Yamanaka, 1979; Pinnavaia et al., 1985; Volzone et al., 1993; Volzone, 1998; Volzone and Tavani, 1995; Tavani and Volzone, 1997). Kaolinites, illites, vermiculites and smectites can be used as clays in order to obtain chromium clays. Some final products obtained from thermally treated chromium clay thermally treated can be suitable for use as materials in the ceramic industries. It is known that the products of the smectite clays fired at high temperature depend on the composition of the clay (Mackenzie and Caillere, 1979). Smectite clays containing different proportions of silicon, aluminum, iron and magnesium, in the layers of the structure and calcium, sodium and potassium as exchangeable cations in interlayer positions result in products such as mullite, cordierite, hematite, anorthite, quartz, etc. after heating at $1000{ }^{\circ} \mathrm{C}$ in air (Volzone and Cesio, 1997). On the other hand, the same thermal treatment conditions as those used with smectites treated previously with $\mathrm{OH}-\mathrm{Cr}$ species gave eskolaite $\left(\alpha-\mathrm{Cr}_{2} \mathrm{O}_{3}\right)$ as the only chromium compound. Other phases belonging to each smectite clay were also present. Reinke et al. (1986) observed that the atmosphere during the heating of chromitemagnesia minerals influenced the structural and mineralogical properties of the final refractory products. There is little information on the Cr clays heated in nitrogen at high temperatures. Nevertheless, depending on the products obtained, they may be used in structural ceramic applications.

Smectites are a group of clay minerals. They are 2:1 layer phyllositicates, where two $\mathrm{Si}^{4+}$ tetrahedral sheets are separated by one $\mathrm{Al}^{3+}$ octahedral sheet.

*To whom correspondence should be addressed 
Different isomorphic substitutions in the octahedral and tetrahedral sheets result in the members of the smectite clay group (MacEwan and Wilson, 1980) with charge in balance, which is balanced by interlayer cations. There are two different series of smectites, dioctahedral and trioctahedral, according to whether the total number of ions in sixcoordination per half unit-cell layer is close to 2.00 or 3.00, respectively.

The aim of this paper is to evaluate the products of the different intercalated chromium-smectite clays heated to $1350{ }^{\circ} \mathrm{C}$ in nitrogen.

\section{MATERIALS AND METHODS}

The smectites used were beidellite, Taiwan, B; NG-1, nontronite, Germany, N; SapCa-1, saponite, U.S.A., S; and LapRD, synthetic laponite (hectorite), supplied by Laporte Inorganics, L. The structural formulae of the smectites (Table 1) were derived from chemical analyses on the basis of an anion charge of -22 (Volzone and Cesio, 1997).

Hydroxy-chromium (OH-Cr) solution was prepared from $0.1 \mathrm{M}$ chromium nitrate solution by addition of $0.2 \mathrm{~N} \mathrm{NaOH}(\mathrm{OH} / \mathrm{Cr}=2)($ Volzone, 1997). The smectite water suspension and the hydroxychromium solution were stirred and after one day the solid was separated and washed several times with distilled water in order to remove the excess electrolyte. The amount of chromium added was 10 mmol per gram of sample.

For the thermal treatments of the $\mathrm{Cr}$ smectites up to $450{ }^{\circ} \mathrm{C}$ and $1350{ }^{\circ} \mathrm{C}$ a Netzsch STA 409 thermobalance was used. The heating rate was $5{ }^{\circ} \mathrm{C}$ $\min ^{-1}$ and treatment was carried out in nitrogen at a flow rate of $50 \mathrm{ml} \mathrm{min}^{-1}$. After thermal treatment the samples were referred to as $\mathrm{Cr}$ smectite $\mathrm{X}$, where smectite is beidellite, nontronite, saponite or laponite and $\mathrm{X}$ is the temperature, $450{ }^{\circ} \mathrm{C}$ or $1350{ }^{\circ} \mathrm{C}$.

Table 1: Half unit-cell formulae of smectites. (d): dioctahedral smectite; $(t)$ : trioctahedral smectite.

\begin{tabular}{|c|c|c|c|c|c|c|c|c|c|c|}
\hline & \multicolumn{2}{|c|}{ Tetrahedral sheet } & \multicolumn{4}{|c|}{ Octahedral sheet } & \multicolumn{4}{|c|}{ Interlayer } \\
\hline Smectite & $\mathrm{Si}_{\mathrm{IV}}{ }^{4+}$ & $\mathrm{Al}_{\mathrm{IV}}{ }^{3+}$ & $\mathbf{A l}_{\mathrm{VI}}{ }^{3+}$ & $\mathrm{Fe}^{3+}$ & $\mathrm{Mg}^{2+}$ & $\mathbf{L i}^{+}$ & $\mathbf{K}^{+}$ & $\mathrm{Na}^{+}$ & $\mathrm{Ca}^{2+}$ & $\mathrm{Mg}^{2+}$ \\
\hline $\mathrm{B}(\mathrm{d})$ & 3.61 & 0.39 & 1.63 & 0.11 & 0.16 & 0 & - & - & 0.06 & - \\
\hline $\mathrm{N}(\mathrm{d})$ & 3.70 & 0.30 & 0.13 & 1.80 & 0.13 & 0 & 0.12 & - & 0.12 & 0.22 \\
\hline$S(t)$ & 3.82 & 0.18 & 0.20 & 0.02 & 2.50 & 0 & 0.16 & 0.18 & 0.10 & - \\
\hline $\mathrm{L}(\mathrm{t})$ & 4.00 & 0 & 0 & 0 & 2.77 & 0.23 & 0.05 & 0.02 & - & - \\
\hline
\end{tabular}

The X-ray diffraction (XRD) samples were obtained with an X-ray X'PERT system using the PW3710 Electronic Control Unit with a Philips 3020 goniometer, $\mathrm{Cu} \mathrm{K} \alpha$ radiation $(\lambda=1.5405 \AA)$ at $40 \mathrm{kV}$ and $20 \mathrm{~mA}$ and Ni filter by scanning at $1^{\circ}(2 \theta) / \mathrm{min}$ between 3 and $70^{\circ}(2 \theta)$. The diffractogram of patterns was measured at room temperature on the powder aggregate sample. The $d(001)$ spacing of all samples was measured on oriented slide specimens at room temperature and $55 \% \mathrm{RH}$ (relative humidity) by scanning at $1 / 2^{\circ}(2 \theta) / \mathrm{min}$ between $3^{\circ}$ and $15^{\circ}(2 \theta)$. To obtain the $55 \% \mathrm{RH}$ in the samples, the oriented slide was put in a chamber containing a saturated $\mathrm{Ca}\left(\mathrm{NO}_{3}\right)_{2} \cdot 4 \mathrm{H}_{2} \mathrm{O}$ solution for one week at room temperature. The chemical composition of the samples was attained by inductively coupled plasma emission spectrometry (ICP).

\section{RESULTS AND DISCUSSION}

The Cr solution contained chromium species such as $\mathrm{Cr}_{n}(\mathrm{OH})_{\mathrm{m}}{ }^{3 \mathrm{n}-\mathrm{m}}$ (Volzone, 1997). The species were intercalated in the smectite clay, and as a consequence, the interlayer cations $\left(\mathrm{Ca}^{2+}, \mathrm{Na}^{+}, \mathrm{K}^{+}\right)$ (Table 1) were replaced by positive chromium species. When the smectites were intercalated, their interlayer spacings increased from 14.9-15.6 (smectites: beidellite, nontronite, saponite, laponite) to $16.5-19.6 \AA$ ( $\mathrm{Cr}$ smectites: $\mathrm{Cr}$ beidellite, $\mathrm{Cr}$ nontronite, $\mathrm{Cr}$ saponite, $\mathrm{Cr}$ laponite) (Table 2) and the different value of interlayer separation was attributed to the amount of retained chromium (Volzone, 2001). Table 1 shows the composition of the saturation interlayer cations $\left(\mathrm{K}^{+}, \mathrm{Na}^{+}, \mathrm{Ca}^{2+}\right.$, $\left.\mathrm{Mg}^{2+}\right)$ which define the different $\mathrm{d}(001)$ spacings of 
the smectite clays (MacEwan and Wilson, 1980). Table 2 shows how these spacings were influenced by the interaction of $\mathrm{OH} \mathrm{Cr}$ species and also how the atmosphere influenced the thermal treatment. When the $\mathrm{Cr}$ smectites were heated at around $450{ }^{\circ} \mathrm{C}$ in air, $\alpha-\mathrm{Cr}_{2} \mathrm{O}_{3}$ appeared (exothermic peak in differential thermal analysis, Volzone and Cesio, 1997, confirmed by X-ray diffraction) and the $\mathrm{d}(001)$ spacing decreased to 9.9-15.5 $\AA$ ( $\mathrm{Cr}$ smectites 450/air) (Table 2). The collapsed value for $\mathrm{Cr}$ nontronite 450/air was associated with dehydroxylation of the 2:1 layer of nontronite that occurs at close to $490{ }^{\circ} \mathrm{C}$ (Mackenzie and Caillere,
1979; Volzone and Cesio, 1997). When the same $\mathrm{Cr}$ smectites were heated in nitrogen at $450{ }^{\circ} \mathrm{C}$, the $\alpha$ $\mathrm{Cr}_{2} \mathrm{O}_{3}$ phase did not appear (no exothermic peak in DTA, as shown in Figure 1) and the d(001) spacings were higher than in air and the values were in the range of 13.8-17.7 $\AA$ (Cr smectites 450/nitrogen) (Table 2). This spacing is produced by some kind of cationic chromium species in the interlayer as pillaring. This type of materials is generally called PILCs (pillared clays), which show textural and acidity characteristics that could enable their use as adsorbents or in catalysis (Pinnavaia et al., 1985; Volzone, 2001).

Table 2: $d(001)$ spacing of the smectites under different conditions.

\begin{tabular}{|l|c|}
\hline Sample & $\mathbf{d}(\mathbf{0 0 1}), \mathbf{A}$ \\
\hline Beidellite & 14.9 \\
Cr beidellite & 16.5 \\
Cr beidellite 450/air & 14.7 \\
Cr beidellite 450/nitrogen & 15.8 \\
Nontronite & 15.6 \\
Cr nontronite & 16.2 \\
Cr nontronite 450/air & 9.9 \\
Cr nontronite 450/nitrogen & 13.8 \\
Saponite & 15.2 \\
Cr saponite & 17.1 \\
Cr saponite 450/air & 15.0 \\
Cr saponite 450/nitrogen & 15.2 \\
Laponite & broad \\
Cr laponite & 19.6 \\
Cr laponite 450/air & 15.5 \\
Cr laponite 450/nitrogen & 17.7 \\
\hline
\end{tabular}

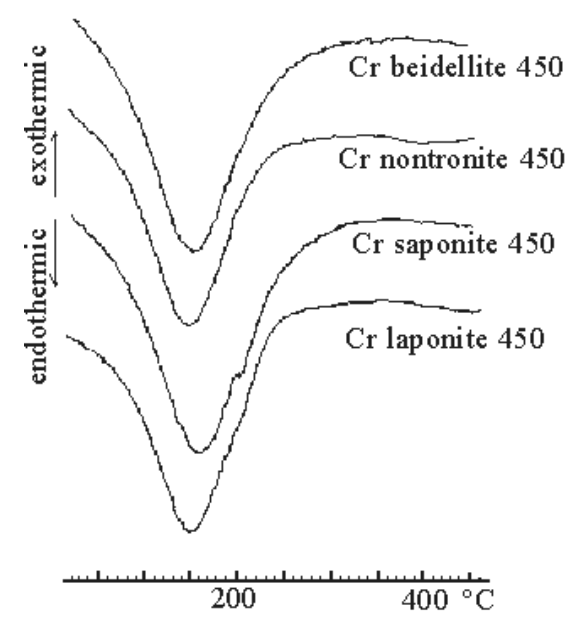

Figure 1: Differential thermal analysis curves for $\mathrm{Cr}$ smectites heated up to $450{ }^{\circ} \mathrm{C}$ in nitrogen. 
Detailed analyses of XRD diagrams of the fired products of $\mathrm{Cr}$ smectites in nitrogen were done and the results are shown in Figures 2-5.

The fired products of the $\mathrm{Cr}$ beidellite 1350 are shown in Figure 2. Due to the considerable amount of amorphous products, the XRD scanning (smooth and magnification) was improved, as shown in the same figure. The phases in this sample were magnesiochromite, (Mg,Fe)O. $(\mathrm{Al}, \mathrm{Cr})_{2} \mathrm{O}_{3} ; \quad$ spinel, MgO. $\mathrm{Al}_{2} \mathrm{O}_{3}$; mullite/sillimanite, $3 \mathrm{Al}_{2} \mathrm{O}_{3} \cdot 2 \mathrm{SiO}_{2} / \mathrm{Al}_{2} \mathrm{O}_{3} \cdot \mathrm{SiO}_{2}$; $\mathrm{SiO}_{2}$ as quartz and amorphous material. Since the major element of $\mathrm{Cr}$ beidellite was aluminum (Table 3), which came from raw smectite, mullite/sillimanite and spinel were the principal compounds. Some of the principal spacings of mullite and sillimanite patterns were not in complete agreement with the powder diffractogram file (Brown, 1980). The iron content in $\mathrm{Cr}$ nontronite produced donathite, $(\mathrm{Fe}, \mathrm{Mg}) \mathrm{O} .(\mathrm{Cr}, \mathrm{Fe})_{2} \mathrm{O}_{3}$, and also chromite iron, $\mathrm{FeO} .(\mathrm{Cr}, \mathrm{Al})_{2} \mathrm{O}_{3}$, at the high temperature $(\mathrm{Cr}$ nontronite 1350) (Figure 3). Cristobalite and quartz plus amorphous products were also found in this fired sample.

$\mathrm{Cr}$ saponite and $\mathrm{Cr}$ laponite contain high percentages of magnesium (Table 3), then clinoenstatite and enstatite, $\mathrm{MgO} . \mathrm{SiO}_{2}$, respectively, were the main phases in those samples (Cr saponite 1350, Figures 4, and $\mathrm{Cr}$ laponite 1350, Figure 5). On the other hand, chromium was present as magnesiochromite $(\mathrm{Mg}, \mathrm{Fe}) \mathrm{O} .(\mathrm{Al}, \mathrm{Cr})_{2} \mathrm{O}_{3}$ and $\mathrm{MgO} . \mathrm{Cr}_{2} \mathrm{O}_{3}$ (picrochromite) in the heated $\mathrm{Cr}$ saponite and $\mathrm{Cr}$ laponite, respectively. Peaks that could correspond to cristobalite were also found. The aluminum contained in saponite (Table 3) produced spinel, $\mathrm{MgO} \cdot \mathrm{Al}_{2} \mathrm{O}_{3}$. No phases containing lithium were found by XRD in Cr laponite 1350. A low content of lithium silicate is probably present but overlapped in the range of 18 to $33^{\circ}(2 \theta)$ in the XRD diagram (Figure 5).

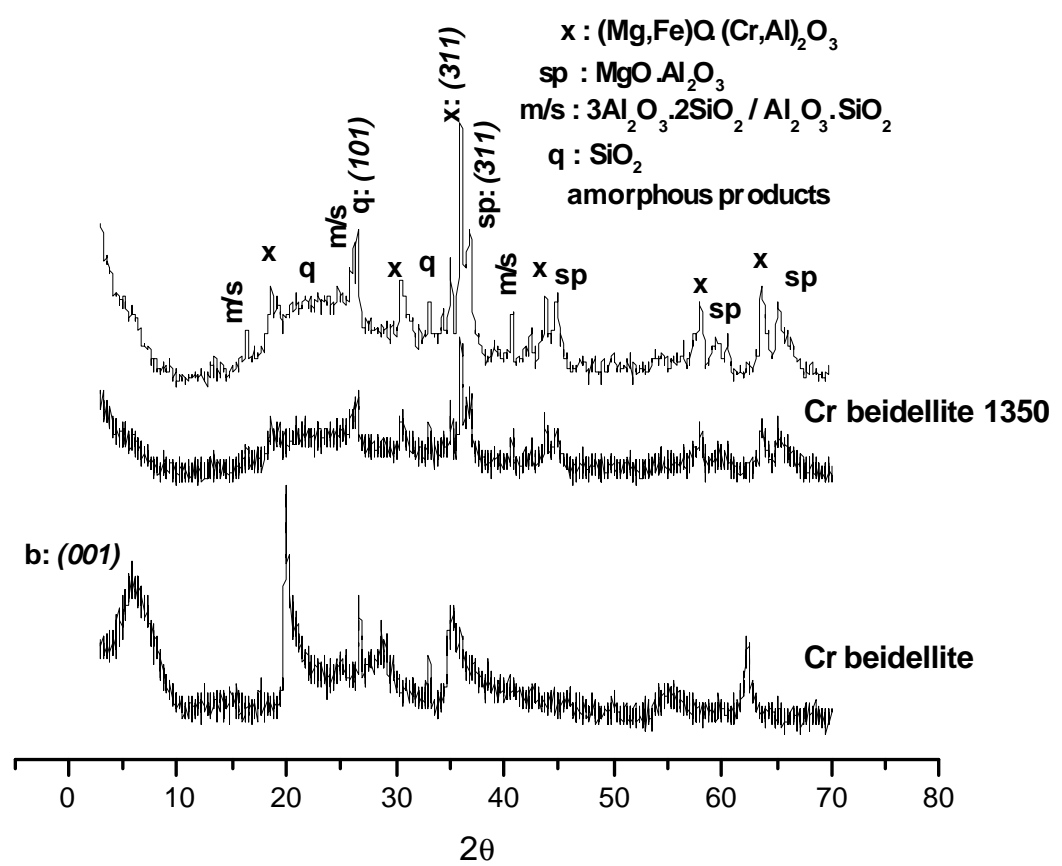

x: magnesiochromite; sp: spinel; m/s: mullite/sillimanite; q: quartz; b: beidellite

Figure 2: XRD patterns of $\mathrm{Cr}$ beidellite, both unfired and fired at $1350{ }^{\circ} \mathrm{C}$ in nitrogen.

Table 3: Elements of smectite structure after chromium treatment, in mmol.

\begin{tabular}{|l|c|c|c|c|c|c|}
\hline $\mathbf{C r}$ smectite & $\mathbf{S i}^{\mathbf{4 +}}$ & $\mathbf{A l}^{\mathbf{3 +}}$ & $\mathbf{F e}^{\mathbf{2 + / 3 +}}$ & $\mathbf{M g}^{\mathbf{2 +}}$ & $\mathbf{L i}^{\mathbf{+}}$ & $\mathbf{C r}^{\mathbf{3 +}}$ \\
\hline Cr beidellite & 679.0 & 176.0 & 20.0 & 38.0 & 0 & 65.0 \\
Cr nontronite & 878.0 & 48.0 & 96.0 & 5.0 & 0 & 56.0 \\
Cr saponite & 620.0 & 32.0 & 4.0 & 455.0 & 0 & 85.0 \\
Cr laponite & 667.0 & 0 & 0 & 367.0 & 45 & 90.0 \\
\hline
\end{tabular}




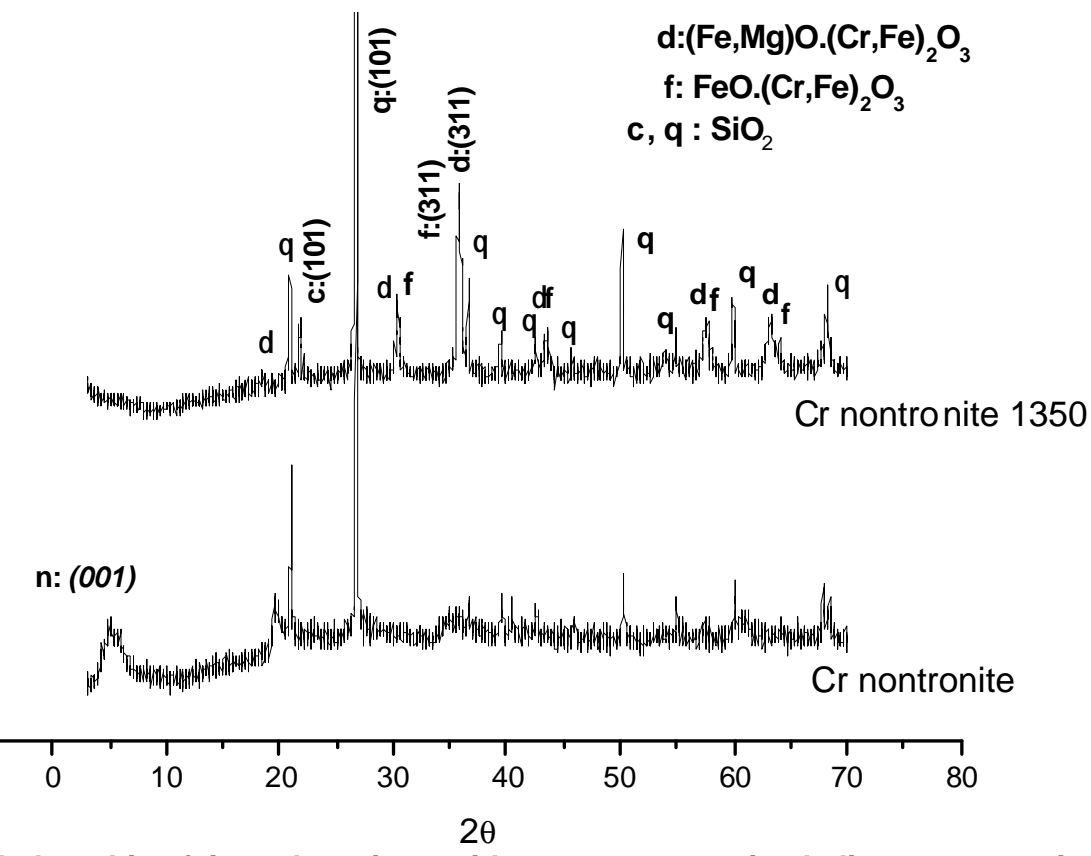

d: donathite; f: iron chromium oxide; q: quartz; c: cristobalite; $n$ : nontronite

Figure 3: XRD patterns of $\mathrm{Cr}$ nontronite, both unfired and fired at $1350{ }^{\circ} \mathrm{C}$ in nitrogen.

Table 4: Products after firing $\mathrm{Cr}$ smectite clays at $1350{ }^{\circ} \mathrm{C}$ in nitrogen.

\begin{tabular}{|c|c|c|}
\hline & Products obtained in nitrogen & \\
\hline \multirow{4}{*}{ Cr beidellite 1350} & $(\mathrm{Mg}, \mathrm{Fe}) \mathrm{O} .(\mathrm{Cr}, \mathrm{Al})_{2} \mathrm{O}_{3}$ magnesiochromite & $13.0 \%$ \\
\hline & $\mathrm{MgO} . \mathrm{Al}_{2} \mathrm{O}_{3}$ spinel & $4.5 \%$ \\
\hline & $3 \mathrm{Al}_{2} \mathrm{O}_{3} \cdot 2 \mathrm{SiO}_{2}$, mullite $/ \mathrm{Al}_{2} \mathrm{O}_{3} \cdot \mathrm{SiO}_{2}$, sillimanite & $14.8 \%$ \\
\hline & $\mathrm{SiO}_{2}$ as quartz + amorphous & $66.7 \%$ \\
\hline \multirow{3}{*}{ Cr nontronite 1350} & $(\mathrm{Fe}, \mathrm{Mg}) \mathrm{O} .(\mathrm{Cr}, \mathrm{Fe})_{2} \mathrm{O}_{3}$ donathite & $13.0 \%$ \\
\hline & $\mathrm{FeO} .(\mathrm{Cr}, \mathrm{Al})_{2} \mathrm{O}_{3}$ iron chromium oxide & $8.3 \%$ \\
\hline & $\mathrm{SiO}_{2}$ as quartz and cristobalite + amorphous & $67.0 \%$ \\
\hline \multirow{4}{*}{ Cr saponite 1350} & $(\mathrm{Mg}, \mathrm{Fe}) \mathrm{O} .(\mathrm{Cr}, \mathrm{Al})_{2} \mathrm{O}_{3}$ magnesiochromite & $37.5 \%$ \\
\hline & $\mathrm{MgO} . \mathrm{Al}_{2} \mathrm{O}_{3}$ spinel & $2.8 \%$ \\
\hline & $\mathrm{MgO} . \mathrm{SiO}_{2}$ clinoenstatite & $44.9 \%$ \\
\hline & $\mathrm{SiO}_{2}$ cristobalite & $14.8 \%$ \\
\hline \multirow{3}{*}{ Cr laponite 1350} & $\mathrm{MgO} \cdot \mathrm{Cr}_{2} \mathrm{O}_{3}$ picrocromite (magnesiochromite) & $12.9 \%$ \\
\hline & $\mathrm{MgO} . \mathrm{SiO}_{2}$ enstatite & $56.0 \%$ \\
\hline & $\mathrm{SiO}_{2}$ cristobalite & $20.7 \%$ \\
\hline
\end{tabular}

The chemical compositions of the $\mathrm{Cr}$ smectite clays are shown in Table 3. The amount of retained chromium was different for each smectite clay, and according to a previous paper, the retention of chromium by natural clays is a function of the number of charges in octahedral positions in the structure (Volzone, 1998). Taking into account the chemical composition of each Cr-smectite clay
(Table 3) and the results of the XRD patterns, it was possible to estimate the relative composition of the present phases (Table 4). The relative percentages of $\mathrm{Cr}$ phases at high temperature were in the range of 13$37 \%$, depending on the original type of smectite and chromium retained. Contrary to what was found in $\mathrm{Cr}$ smectites fired in air at $1000{ }^{\circ} \mathrm{C}$ (Volzone and Cesio, 1997) no $\alpha-\mathrm{Cr}_{2} \mathrm{O}_{3}$ was detected in our fired products. 


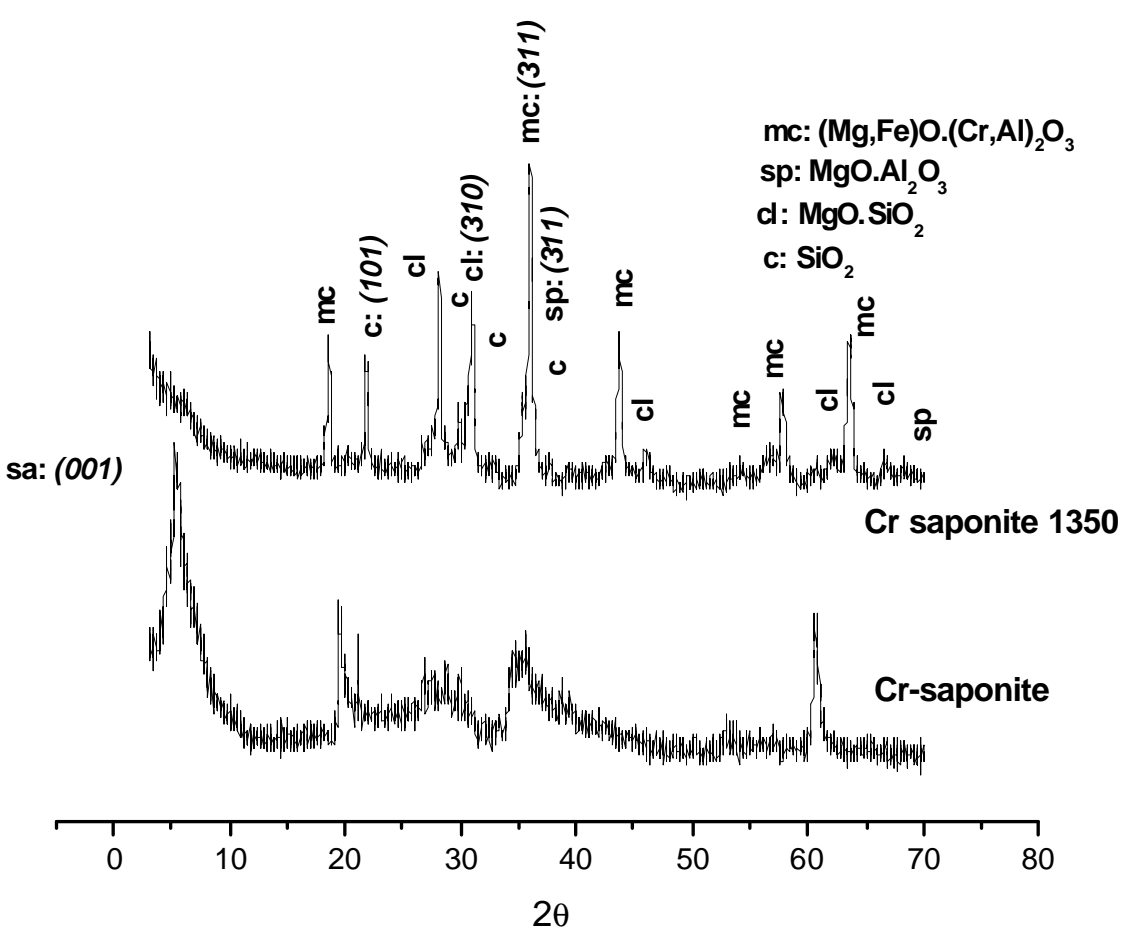

mc:magnesiochromite; sp:spinel; cl:clinoenstatite; c:cristobalite; sa:saponite

Figure 4: XRD patterns of $\mathrm{Cr}$ saponite, both unfired and fired at $1350{ }^{\circ} \mathrm{C}$ in nitrogen.

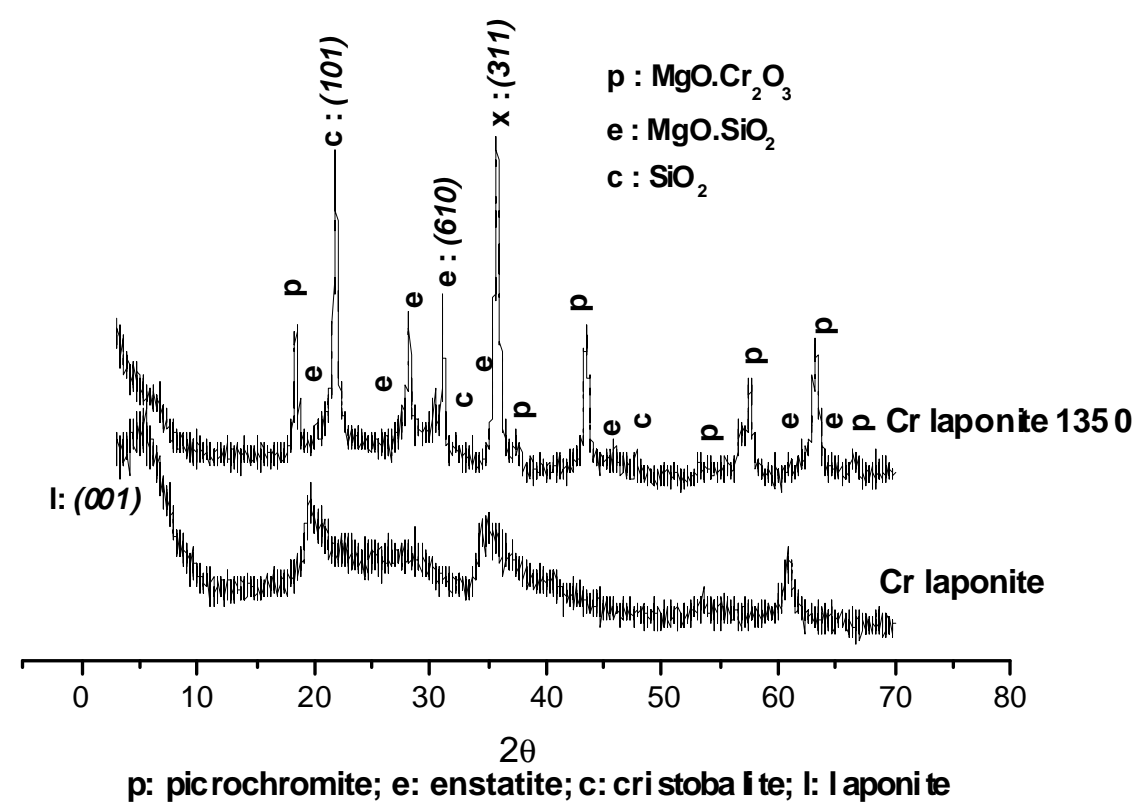

Figure 5: XRD patterns of $\mathrm{Cr}$ laponite, both unfired and fired at $1350{ }^{\circ} \mathrm{C}$ in nitrogen. 


\section{CONCLUSIONS}

The original composition of smectite clays and retained chromium influenced the kind of products obtained at $1350{ }^{\circ} \mathrm{C}$ in nitrogen.

The chromium products obtained by heating to $1350{ }^{\circ} \mathrm{C}$ in nitrogen of the chromium-intercalated smectites, range from magnesio-chromium oxides, which contain $\mathrm{Al}$ and $\mathrm{Fe}$, to picrochromite $\mathrm{MgO} . \mathrm{Cr}_{2} \mathrm{O}_{3}$. Heating under these conditions, applied to intercalated clays with chromium from polymeric solutions or from wastewater, would result in similar potential industrial products.

The $\alpha-\mathrm{Cr}_{2} \mathrm{O}_{3}$ phase that was found in Cr-smectite clays heated in air up to $1000{ }^{\circ} \mathrm{C}$ (Volzone and Cesio, 1997) was not found in the same Cr-smectite clays fired in nitrogen.

\section{REFERENCES}

Brindley, G.W. and Yamanaka, S., A study of Hydroxy-Chromium Montmorillonites and the Form of the Hydroxy-Chromium Polymers, Amer. Mineral., 64, 830 (1979).

Brown, G., in Crystal Structures of Clays Minerals and Their X-ray Identification, G.W. Brindley and G. Brown, eds., 361-410; London, Mineralogical Society (1980).

Carr, M.R., Hydration States of Interlamellar Chromium Ions in Montmorillonites, Clays \& Clays Miner., 33, 357 (1985).

MacEwan, D.M.C. and Wilson, M.J., in Crystal Structures of Clays Minerals and Their X-ray Identification, G.W. Brindley and G. Brown, eds., 197-248; London, Mineralogical Society (1980).

Mackenzie, R.C. and Caillere, S., in Data Handbook for Clay Materials and Other Nonmetallic Minerals, H. van Olphen and J.J. Fripiat, eds., 243; Pergamon Press Inc. (1979).

Pinnavaia, T.J., Tzou, M.S. and Landau, S.D., New Chromia Pillared Clay Catalyst, J. Am. Chem.
Soc., 107, 4783 (1985).

Reinke, H., Hern, H. and Ambs, H., The Effect of Oxidizing and Reducing Atmospheres on the Mineralogical, Microstructural and Physical Properties of Chrome-Magnesia Refractories, $\mathrm{Br}$. Ceram. Trans. J., 85, 188 (1986).

Rengasamy, P. and Oades, J.M., Interactions of Monomeric and Polymeric Species of Metal Ions with Clay Surfaces. III Aluminium (III) and Chromium (III), Aust. J. Soil Res., 16, 53 (1978).

Tavani, E.L. and Volzone, C., Adsorption of Chromium (III) from a Tanning Wastewater on Kaolinite, J. Soc. Leather Technol. Chem., 81, 143 (1997).

Volzone, C., Changes in Kaolinite, Vermiculite, and Smectite Clays after Adsorption by HydroxyChromium Species, Aust. J. Soil Res., 36, 423 (1998).

Volzone, C., OH-Cr(III) in Dioctahedral and Trioctahedral Smectites: Texture and Structure Changes, Mater. Chem. Phys., 47, 13 (1997).

Volzone, C., Pillaring of Different Smectite Members by Chromium Species (Cr-PILCs), Microporous and Mesoporous Materials, 49, 197 (2001).

Volzone, C. and Cesio, A.M., Structural Modifications of $\mathrm{OH}-\mathrm{Cr}$ Smectites after Thermal Treatment up to $1000{ }^{\circ} \mathrm{C}$, Mater. Chem. Phys., 48, 216 (1997).

Volzone, C., Cesio, A.M., Torres Sánchez, R.M. and Pereira, E., Hydroxy-Chromium Smectite, Clays and Clay Miner., 41, 702 (1993).

Volzone, C., Garrido, L.B., Ortiga, J, and Pereira, E., in Desarrollo de Adsorbentes para la Separación de Gases - Subprograma V: Catálisis y Adsorbentes, Proyecto V.3. CYTED, F. Rodríguez-Reinoso and P. Andreu, eds., 97-119; CYTED, Spain (1998).

Volzone, C. and Tavani, E.L., Chromium (III) Adsorption on Smectite from a Tanning Wastewater, J. Soc. Leather Technol. Chem., 79, 148 (1995). 